\title{
Effects of dose and concentration of rectal methohexitone for induction of
}

R.S. Laishley MB FFARCS, A.C. O'Callaghan MB FFARCS, $J$. Lerman MD FRCPC
To investigate the effect of dose and concentration of rectal methohexitone for induction of anaesthesia, 60 children (ASA physical starus 1 or 2) undergoing outpatient surgery were studied. Each child was randomly assigned to receive one of three rectal solutions (each containing atropine $0.02 \mathrm{mg} \cdot \mathrm{kg}^{-1}$ ): Group A - ten per cent methohexitone, $25 \mathrm{mg} \cdot \mathrm{kg}^{-1}(n=20)$; Group B - ten per cent methohexitone, $15 \mathrm{mg} \cdot \mathrm{kg}^{-1}(n=20)$; or Group C - one per cent methohexitone, $15 \mathrm{mg} \cdot \mathrm{kg}^{-1}(n=20)$. After induction of anaesthesia, or a maximum period of 20 minutes following rectal administration of methohexitone, halothane, nitrous oxide, and oxygen were administered by mask. The time to induction of anaesthesia, complications, postanaesthetic recovery scores, and recovery time did not differ significantly among the three groups. The incidence of failed inductions did not differ significantly between Group A (zero per cent) and Group $C$ (ten per cent) but both were significantly less than Group B (45 per cent) $(p<0.05)$. Heart rate increased significantly between 10 and 30 minutes after rectal

\section{Key words}

AGE: paediatrics; ANAESTHETIC: rectal atropine, rectal methohexitone.

From the Department of Anaesthesia and Research Institute, The Hospital for Sick Children, University of Toronto, Toronto, Ontario.

Address correspondence to: Dr. Jerrold Lerman, Department of Anaesthesia, The Hospital for Sick Children, 555 University Avenue, Toronto, Ontario, M5G 1 X8. administration of methohexitone and atropine. The authors conclude that ten per cent rectal methohexitone $25 \mathrm{mg} \cdot \mathrm{kg}^{-1}$ and one per cent rectal methohexitone 15 $\mathrm{mg} \cdot \mathrm{kg}^{-1}$ are equally effective for induction of anaesthesia in children and both are significantly more effective than ten per cent methohexitone $15 \mathrm{mg} \cdot \mathrm{kg}^{-1}$.

Rectal methohexitone is both safe and effective for induction of anaesthesia in children. ${ }^{1-6}$ The administration of rectal methohexitone avoids the anxiety associated with needle puncture, mask induction, and parental separation at induction of anaesthesia. ${ }^{4,5}$ Several doses and concentrations of rectal methohexitone have been used. Orallo and Eather reported that $22 \mathrm{mg} \cdot \mathrm{kg}^{-1}$ rectal methohexitone in solutions between 2.5 and 10 per cent were equally effective for sedation in children. ${ }^{2}$ Recently, several investigators have reported that ten per cent methohexitone, $25 \mathrm{mg} \cdot \mathrm{kg}^{-1}$, had a rapid onset of action, reliably induced anaesthesia, and did not prolong recovery. ${ }^{4-6}$ However, rectal irritation and mucosal injury have been reported following the use of ten per cent rectal methohexitone in mice. ${ }^{7}$ Furthermore, wide variations in the plasma concentration of methohexitone have been reported following administration of the same solution. ${ }^{8} \mathrm{We}$ speculated that a lower concentration and a lower total dose of rectal methohexitone might be as effective as a ten per cent solution, $25 \mathrm{mg} \cdot \mathrm{kg}^{-1}$, for induction of anaesthesia and might also avoid these problems.

Coleman and Green recommended a one per cent solution of rectal methohexitone for induction of anaesthesia, although there are no controlled 
studies with this concentration.' Orallo and Eather reported that a 1.5 per cent solution of rectal methohexitone $10-15 \mathrm{mg} \cdot \mathrm{kg}^{-1}$, did not reliably sedate children when compared to $2.5-10$ per cent solutions containing $22 \mathrm{mg} \cdot \mathrm{kg}^{-1}$. $^{2}$ The effectiveness of a one per cent solution of rectal methohexitone remains undetermined. Therefore, in order to determine the effects of dose and concentration of methohexitone for induction of anaesthesia in children, we compared the clinical effectiveness, side effects, and complications of rectal methohexitone in a ten per cent solution, $25 \mathrm{mg} \cdot \mathrm{kg}^{-1}$; ten per cent solution, $15 \mathrm{mg} \cdot \mathrm{kg}^{-1}$; and one per cent solution, $15 \mathrm{mg} \cdot \mathrm{kg}^{-1}$, in children undergoing out-patient surgery.

\section{Methods}

With approval from the Committee on Human Research, written informed consent was obtained from the parents of 60 children, ages six months to six years, scheduled for out-patient herniomhaphy or orchidopexy. All children were fasted, ASA physical status 1 or 2, and unpremedicated. None of the children received an enema preoperatively. Each child was randomly assigned to receive one of the following solutions of rectal methohexitone: Group A - ten per cent solution, $25 \mathrm{mg} \cdot \mathrm{kg}^{-1}$; Group $B$ - ten per cent solution, $15 \mathrm{mg} \cdot \mathrm{kg}^{-1}$; or Group C - one per cent solution, $15 \mathrm{mg} \cdot \mathrm{kg}^{-1}$. Atropine $\left(0.6 \mathrm{mg} \cdot \mathrm{ml}^{-1}\right) 0.02 \mathrm{mg} \cdot \mathrm{kg}^{-1}$ was added to all solutions.

With the parents present, rectal methohexitone was administered through a lubricated 12 gauge soft plastic suction catheter inserted approximately $3 \mathrm{~cm}$ into the rectum of each child, in a room adjacent to the operating room. Resuscitation equipment was present at the bedside. After administration of the rectal solution, approximately $2 \mathrm{ml}$ of air were injected through the catheter to clear the deadspace. Following the onset of sleep (defined below) or a maximum observation period of 20 minutes after administration of the methohexitone, each child was transferred to the operating room and anaesthetized with halothane 0.5 to 2 per cent (vaporizer setting) and 66 per cent nitrous oxide in oxygen.

If methohexitone failed to induce anaesthesia, then the child was anaesthetized with either intravenous thiopentone $5 \mathrm{mg} \cdot \mathrm{kg}^{-1}$ with atropine 0.02 $\mathrm{mg} \cdot \mathrm{kg}^{-1}$ or halothane, nitrous oxide, and oxygen.
A regional field block consisting of bupivacaine 0.5 per cent (1-2 $\left.\mathrm{mg} \cdot \mathrm{kg}^{-1}\right)$ with epinephrine $(1: 200,000)$ was administered to each child for postoperative anaglesia. If pain was present in the postoperative period, then either oral acetaminophen (10 $\mathrm{mg} \cdot \mathrm{kg}^{-1}$ ) or intramuscular codeine $\left(1.5 \mathrm{mg} \cdot \mathrm{kg}^{-1}\right)$ was given, depending on the severity of the pain.

Induction time was defined as the time interval from the administration of methohexitone to the onset of sleep. The onset of sleep was defined as loss of consciousness, loss of the eyelash reflex, absence of voluntary or purposeful movements and unresponsiveness to verbal stimulation.

Heart rate and systolic blood pressure were recorded immediately before (baseline) and every five minutes after the administration of methohexitone until completion of surgery. The postanaesthetic recovery scores, ${ }^{9}$ recovery time, and incidence of complications were also recorded. Recovery time was defined as the time interval between admission to the postanaesthesia room (PAR) and discharge from hospital.

Statistical significance $(p<0.05$ ) was determined using the Chi-square analysis with Yates correction and the Fisher exact test for the incidence of failed inductions, the incidence of complications and the unpaired t-test, ANOVA, and the StudentNewman-Keuls test for the age, weight, induction time, recovery time, and heart rate between groups and within groups.

\section{Results}

Sixty children were divided into three equal groups (Table I). The mean age and weight did not differ significantly among the groups. The induction times for those children who fell asleep with rectal methohexitone did not differ significantly among the three groups (Table II). The incidence of failed

TABLE I Demographic data

\begin{tabular}{llll}
\hline & $\begin{array}{l}\text { Group A } \\
10 \%\end{array}$ & $\begin{array}{l}\text { Group B } \\
10 \%\end{array}$ & $\begin{array}{l}\text { Group C } \\
1 \% \\
\text { Rectal }\end{array}$ \\
methohexitone & $25 \mathrm{mg} \cdot \mathrm{kg}^{-1}$ & $15 \mathrm{mg} \cdot \mathrm{kg}^{-1}$ & $15 \mathrm{mg} \cdot \mathrm{kg}^{-1}$ \\
\hline Number of patients & 20 & 20 & 20 \\
Age (yrs) & $3.18 \pm 0.4$ & $2.96 \pm 0.38$ & $2.96 \pm 0.32$ \\
Weight (kg) & $15.3 \pm 0.62$ & $13.9 \pm 0.94$ & $14.6 \pm 0.71$ \\
\hline
\end{tabular}

Mean \pm SEM 
TABLE II Induction and recovery data

\begin{tabular}{llll}
\hline & $\begin{array}{l}\text { Group A } \\
10 \%\end{array}$ & $\begin{array}{l}\text { Group B } \\
10 \%\end{array}$ & $\begin{array}{l}\text { Group C } \\
1 \%\end{array}$ \\
$\begin{array}{l}\text { Recral } \\
\text { methohexitone }\end{array}$ & $25 \mathrm{mg} \cdot \mathrm{kg}^{-1}$ & $15 \mathrm{mg} \cdot \mathrm{kg}^{-1}$ & $15 \mathrm{mg} \cdot \mathrm{kg}^{-1}$ \\
\hline $\begin{array}{c}\text { Incidence of failed } \\
\text { induction (\%) } \\
\begin{array}{c}\text { Induction time } \\
\text { (min) }\end{array}\end{array}$ & $0 / 20(0)$ & $9 / 20^{*}(45)$ & $2 / 20(10)$ \\
$\begin{array}{c}\text { Recovery time } \\
\text { (min) }\end{array}$ & $8.1 \pm 0.5$ & $9.2 \pm 0.8$ & $7.5 \pm 0.5$ \\
\hline
\end{tabular}

Mean \pm SEM

${ }^{*} p<0.05$ Group B compared with Groups A and C.

$\mathrm{p}=\mathrm{NS}$; Group A compared with Group $\mathrm{C}$.

$\mathrm{p}=\mathrm{NS}$; Induction and recovery times.

Induction times include only those children who fell asleep

following methohexitone.

inductions did not differ significantly among Group A (zero per cent) and Group C (ten per cent). However, the incidence of failed inductions was significantly greater with Group B (45 per cent) compared with the other two solutions $(p<0.05)$.

The baseline heart rate did not differ significantly among the three groups. Heart rate increased significantly after ten minutes in those children who fell asleep following both the ten per cent solution, $25 \mathrm{mg} \cdot \mathrm{kg}^{-1}$, and the one per cent solution, $15 \mathrm{mg} \cdot \mathrm{kg}^{-1}$ ( $\mathrm{p}<0.05$ ) (Figure). In contrast, the heart rate did not increase significantly until 30 minutes in those children who fell asleep following ten per cent methohexitone $15 \mathrm{mg} \cdot \mathrm{kg}^{-1}(p<0.05)$. The coefficient of variation of the heart rates were 14 per cent for Group A, 18 per cent for Group B, and 14 per cent for Group C.

Systolic blood pressure did not change significantly for the three groups during the study period.

The incidence of complications did not differ

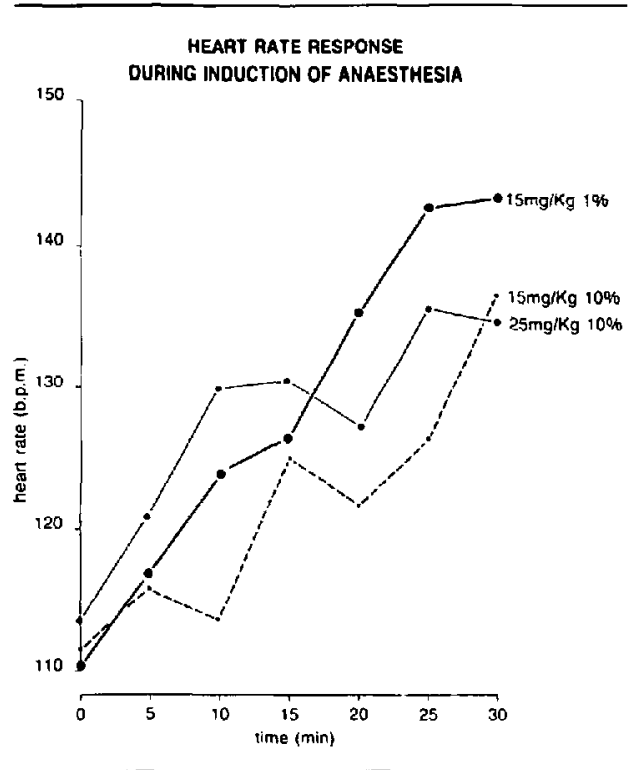

FIGURE Mcan heart rates for the three groups of children who fell asleep following rectal methohexitone. Heart rate increased significantly above awake values by ten minutes in Group $\mathrm{A}$ and Group C; however, heart rate did not increase significantly until 30 minutes in Group $B(p<0.05)$.

significantly among the three groups (Table III). The occurrence of soiling did not preclude induction of anaesthesia with methohexitone. Hiccoughs occurred in all three treatment groups. One child who was apnoeic for ten minutes following the onset of sleep, required assisted ventilation by mask. Two other children who develped laryngospasm after transfer into the operating room required intravenous succinylcholine and tracheal intubation. All three of these children who de-

TABLE II] Complications after rectal methohexitone

\begin{tabular}{|c|c|c|c|c|}
\hline $\begin{array}{l}\text { Rectal } \\
\text { methohexitone }\end{array}$ & $\begin{array}{l}\text { Group A } \\
10 \% \\
25 \mathrm{mg} \cdot \mathrm{kg}^{-1}\end{array}$ & $\begin{array}{l}\text { Group B } \\
10 \% \\
15 \mathrm{mg} \cdot \mathrm{kg}^{-1}\end{array}$ & $\begin{array}{l}\text { Group C } \\
1 \% \\
15 \mathrm{mg} \cdot \mathrm{kg}^{-1}\end{array}$ & $\begin{array}{l}\text { Total } \\
\text { Incidence }(\%)\end{array}$ \\
\hline Soiling & 2 & 2 & 4 & $8 / 60(13)$ \\
\hline Hiccoughs & 1 & 2 & 2 & $5 / 60 \quad(8)$ \\
\hline Apnoea & 1 & 0 & 0 & $1 / 60 \quad(2)$ \\
\hline Laryngospasm & 2 & 0 & 0 & $2 / 60 \quad(3)$ \\
\hline $\begin{array}{l}\text { Intravenous atropine } \\
\text { for bradycardia }\end{array}$ & 2 & 4 & 1 & $7 / 60(12)$ \\
\hline
\end{tabular}

Between group comparisons. $\mathrm{p}=\mathrm{NS}$. 
veloped airway problems had received ten per cent methohexitone, $25 \mathrm{mg} \cdot \mathrm{kg}^{-1}$. Seven children required supplemental intravenous atropine for bradycardia, defined as a heart rate less than 100 beats per minute.

The recovery scores and recovery times did not differ significantly among the children who fell asleep following rectal methohexitone (Table II). For those children who fell asleep following ten per cent methohexitone $25 \mathrm{mg} \cdot \mathrm{kg}^{-1}$ or ten per cent methohexitone $15 \mathrm{mg} \cdot \mathrm{kg}^{-1}$, codeine administration did not affect their recovery times. However, for those children who fell asleep with one per cent methohexitone, $15 \mathrm{mg} \cdot \mathrm{kg}^{-1}$, codeine $(\mathrm{n}=7) \mathrm{sig}$ nificantly prolonged the recovery times (mean $103.6 \mathrm{~min})$ compared to those children $(\mathrm{n}=11)$ who did not receive codeine (mean $69.5 \mathrm{~min})(\mathrm{p}<$ 0.05 ).

\section{Discussion}

This study demonstrates that one per cent methohexitone, $15 \mathrm{mg} \cdot \mathrm{kg}^{-1}$, and ten per cent methohexitone, $25 \mathrm{mg} \cdot \mathrm{kg}^{-1}$, are equally effective for induction of anaesthesia in children. Rectal methohexitone in a dose of $15 \mathrm{mg} \cdot \mathrm{kg}^{-1}$ is reliably effective only when administered in a large volume (i.e., one per cent solution). The failure of rectal methohexitone, $15 \mathrm{mg} \cdot \mathrm{kg}^{-1}$, to induce anaesthesia when administered in a small volume (i.e., ten per cent solution) is in agreement with previous studies. ${ }^{3}$ We conclude that the effectiveness of rectal methohexitone for induction of anaesthesia in children depends on both the dose of methohexitone administered and the volume of the solution.

The results of this study are in close agreement with previous studies. For Group A, the time for induction of anaesthesia (mean $8.1 \mathrm{~min}$ ) and the incidence of failed inductions (zero per cent) are similar to those reported previously. ${ }^{4-6,8}$ For Group $\mathrm{B}$, the $\mathbf{4 5}$ per cent incidence of failed inductions is also consistent with previous studies. ${ }^{2,3}$ As a result of these latter studies, a minimum dose of $20 \mathrm{mg} \cdot \mathrm{kg}^{-1}$ methohexitone in a ten per cent solution has been recommended. ${ }^{5}$

Liu et al., measured the plasma concentration of methohexitone after administration of a ten per cent solution, $25 \mathrm{mg} \cdot \mathrm{kg}^{-1} \cdot{ }^{8}$ They found a large variability in the plasma concentration of methohexitone. Liu et al., suggested that the variability in plasma concentration which occurs following administra- tion of a small volume of methohexitone (i.e., a ten per cent solution) may result from several factors including absorption of methohexitone by faeces and diversion of methohexitone into the portal venous circulation. ${ }^{8}$ The plasma concentration of methohexitone depends in part on the site of absorption from the rectum. ${ }^{8}$ Solutions deposited in the lower third of the rectum are absorbed directly into the systemic circulation via the inferior haemorrhoidal veins. In contrast, solutions deposited in the upper two-thirds of the rectum are absorbed into the portal venous circulation via the middle and superior haemorrhoidal veins. ${ }^{10}$ Absorption of methohexitone into the portal venous circulation is undesirable, because first-pass hepatic metabolism $^{11,12}$ decreases the systemic bioavailability (hepatic extraction ratio of 0.5 ). ${ }^{12}$ Therefore, rectal solutions should be deposited in the lower third of the rectum.

We speculate that the larger volume of rectal solution administered in a one per cent concentration results in more efficient rectal absorption of methohexitone and therefore in higher plasma concentrations than that of a ten per cent concentration. Therefore, the effective dose required may be reduced from $25 \mathrm{mg} \cdot \mathrm{kg}^{-1}$ to $15 \mathrm{mg} \cdot \mathrm{kg}^{-1}$. Further studies are required to determine the effect of a one per cent solution $15 \mathrm{mg} \cdot \mathrm{kg}^{-1}$ on the plasma concentration of methohexitone in children.

Rectal methohexitone has been shown to induce rectal mucosal irritation and injury. Hinkle and Weinlander reported that rectal irritation occurs following instillation of ten per cent methohexitone in children. ${ }^{7}$ They have also demonstrated that ten per cent methohexitone causes rectal mucosal irritation and injury in mice. ${ }^{7}$ This injury was first attributed to the hyperosmolarity $\left(819 \mathrm{mOsm} \cdot \mathrm{L}^{-1}\right)$ of the ten per cent solution. However, more recent evidence suggests that at least in mice, this injury may in part, result from a direct effect of methohexitone on rectal mucosa. ${ }^{14}$ This mucosal irritation may be similar to the pain reported after intravenous administration of methohexitone. In the latter case, the addition of a small dose of lidocaine to the methohexitone prevents the pain after intravenous injection. ${ }^{15}$ There have been no reports of rectal mucosal injury in humans following rectal instillation of a one per cent methohexitone solution ( $82 \mathrm{mOsm} \cdot \mathrm{L}^{-1}$ ). Because one per cent methohexitone is hypo-osmolar, we speculate that a 
one per cent solution of methohexitone may not cause mucosal irritation. ' However, if this irritation is similar to that which occurs after intravenous injection, the addition of a small dose of lidocaine to rectal solutions of methohexitone may be indicated.

We found that rectal instillation of atropine significantly increased the heart rate in those children who fell asleep with rectal methohexitone. Heart rate increased significantly following the onset of sleep with either Group A or Group C. In contrast, heart rate did not increase significantly in those children who fell asleep in Group B until 30 minutes after administration of the methohexitone (coincidental with surgical incision in 69 per cent of cases). Thus, the time to a significant increase in heart rate ranged from 10-30 minutes.

Olsson et al, have shown that the peak plasma atropine concentrations occurred 15-30 minutes after administration of the rectal solution. ${ }^{16}$ They recommended that 30 minutes should elapse following rectal instillation of atropine $\left(0.02 \mathrm{mg} \cdot \mathrm{kg}^{-1}\right)$ to ensure maximum vagal protection. Furthermore, the peak plasma concentration of atropine after rectal instillation was only one-third the plasma concentrations following intramuscular administration. ${ }^{16}$ In this study, seven children required intravenous atropine for heart rates less than 100 beats per minute and all of these occurred within 30 minutes of rectal instillation of atropine. Because the induction of anaesthesia is more rapid with rectal methohexitone than the onset of the vagolytic effect of rectal atropine, intravenous access is recommended in all children anaesthetized with rectal methohexitone in case supplemental atropine is required. Further studies are necessary to establish the time course and extent of the vagal blockade following rectal instillation of atropine.

There was no significant difference in the incidence of complications among the three treatment groups (Table III). It has been suggested that when a large volume of solution is administered per rectum, soiling may occur. Although several children did soil during this study, there was no significant difference in the incidence among the three groups. The total incidence of soiling (13 per cent) is similar to that reported previously. ${ }^{4,5,8}$ Three children who developed apnoea and laryngospasm received ten per cent methohexitone $25 \mathrm{mg} \cdot \mathrm{kg}^{-1}$. It has been suggested that doses of rectal methohexitone in excess of $22 \mathrm{mg} \cdot \mathrm{kg}^{-1}$ may be associated with respiratory complications. ${ }^{3}$ Laryngospasm following administration of ten per cent methohexitone, $25 \mathrm{mg} \cdot \mathrm{kg}^{-1}$, may be attributed to a light level of anaesthesia. Although there was no significant difference in the incidence of respiratory complications among the three groups, we speculate that as a result of a more predictable absorption of methohexitone and a deeper level of anaesthesia the one per cent solution may cause fewer respiratory complications.

Although there was no significant difference in recovery scores and recovery times among the three groups, it was interesting to note that the postoperative administration of codeine prolonged the recovery times for those children who received one per cent methohexitone, $15 \mathrm{mg} \cdot \mathrm{kg}^{-1}$. The explanation of this is unclear. We recommend that postoperative codeine be administered cautiously in children receiving this concentration of methohexitone.

In conclusion, we found that one per cent rectal methohexitone, $15 \mathrm{mg} \cdot \mathrm{kg}^{-1}$, and ten per cent methohexitone, $25 \mathrm{mg} \cdot \mathrm{kg}^{-1}$, were equally effective for induction of anaesthesia in children. In contrast, ten per cent methohexitone, $15 \mathrm{mg} \cdot \mathrm{kg}^{-1}$, was significantly less effective $(p<0.05)$. We found that the effectiveness of methohexitone depended on both the dose of methohexitone administered and the volume of the solution used. In view of the potential problems associated with the ten per cent solution, we recommend the use of one per cent rectal methohexitone, $15 \mathrm{mg} \cdot \mathrm{kg}^{-1}$, with atropine $0.02 \mathrm{mg} \cdot \mathrm{kg}^{-1}$ for induction of anaesthesia in children.

\section{Acknowledgements}

The authors thank Dr. B. Shandling for his encouragement and cooperation during surgery, Ms. S. Pickering and the nurses in Day Care Surgery for their assistance in completing this study, and Ms. T. Cain for her assistance in preparing this manuscript.

\section{References}

1 Coleman I, Green RA. Methohexital. A short acting barbiturate. Anaesthesia 1960, 15: 411-23.

2 Orallo $M O$, Eather $K F$. Sodium methohexital as a rectal agent in pediatric anesthesia. A controlled comparison with sodium thiamylal. Anesth Analg 1965, 44: 97-103. 
3 Budd DC, Dornett WHL, Wright JF. Methohexital for rectal basal narcosis. Anesth Analg 1965, 44: 222-5.

4 Goresky GV, Steward DJ. Rectal methohexitone for induction of anaesthesia in children. Can Anaesth Soc J 1979, 26: 213-5.

5 Liu LMP, Goudsouzian NG, Liu PL. Rectal methohexital premedication in children, a dose-comparison study. Anesthesiology 1980, 53: 343-5.

6 Quaynor $H$, Corbey $M$, Bjorkman $S$. Rectal induction of anaesthesia in children with methohexitone. Br J Anaesth 1985, 57: 573-7.

7 Hinkle AJ, Weinlander $C M$. Rectal mucosal injury after rectal premedication with methohexital. Anesthesiology 1984, 61: A 436.

8 Liu LMP, Gaudreault P, Friedman PA, Goudsouzian NG, Liu PL. Methohexital plasma concentrations in children following rectal administration. Anesthesiology 1985, 62: 567-70.

9 Steward DJ. A simplified scoring system for the post-operative recovery room. Can Anaesth Soc J 1975, 22: 111-3.

10 DeBoer AG, DeLeede LGJ, Breimer DD. Drug absorption by sublingual and rectal routes. $\mathrm{Br} \mathrm{J}$ Anaesth 1984, 56: 69-82.

11 Rowland $M$, Tozer TN. Clinical pharmacokinetics concepts and applications. Philadelphia, Lea and Febiger, 1980, 66-70.

12 Rowland $M$. Influence of route of administration on drug availability. J Pharm Sci 1972, 61: 70-4.

13 Gibaldi $M$, Boyes RN, Feldman S. Influence of first-pass effect on availability of drugs on oral administration. J Pharm Sci 1971, 60: 1338-40.

14 Hinkle AJ, Weinlander $C M$. The rectal toxicology of $10 \%$ methohexital: gross and histological mucosal effects in an animal model. Anesthesiology 1985, 63: A461.

15 Steward DJ. Manual of pediatric anaesthesia. New York, Churchill-Livingstone, 1985 pp. 40-41.

16 Olsson GL, Bejersten A, Feychting $H$ et al. Plasma concentrations of atropine after rectal administration. Anaesthesia 1983, 38: 1179-82.

\section{Résumé}

Afin d'étudier l'effet de la dose et concentration du methohexitone par voie rectale pour l'induction de l'anesthésie, 60 enfants (ASA état I ou II) devant subir une chirurgie en externe ont été étudiés. Chaque enfant a été choisi d'une façon randomisée afin de recevoir une des trois solutions rectales (contenant chacune de l'atropine $0.02 \mathrm{mg} \cdot \mathrm{kg}^{-1}$ ): dix pour cent de methohexitone, $25 \mathrm{mg} \cdot \mathrm{kg}^{-1}(\mathrm{n}=20)$; dix pour cent methohexitone, $15 \mathrm{mg} \cdot \mathrm{kg}^{-1}(\mathrm{n}=20)$; ou un pour cent methohexitone, $15 \mathrm{mg} \mathrm{kg}^{-1}(n=20)$. Après induction de l' anesthésie ou après une période maximale de 20 minures de l'administration du methohexitone par voie rectale, l' halothane, le proxtoxyde d'azote et oxygène ont été administrés par masque. Le temps de l'induction de l'anesthésie, complications, indices de reveil post-anesthésique, et le temps de réveil, n'étaient pas différent d'une façon statistiquement significative dans les trois groupes. L'incidence d'induction manquée n'était pas significativement différente entre le groupe ayant rȩ̧u dix pour cent de methohexitone $25 \mathrm{mg} \cdot \mathrm{kg}^{-1}$ (0 pour cent) et un pour cent methohexitone $15 \mathrm{mg} \cdot \mathrm{kg}^{-1}$ (dix pour cent) alors qu'elle était significativement moindre pour le groupe ayant reçu dix pour cent de methohexitone $15 \mathrm{mg} \cdot \mathrm{kg}^{-1}$ (45 pour cent) $(p<0.05)$. La fréquence cardiaque augmenta significativement entre 10 et 30 minutes après l'administration rectale du methohexitone et l'atropine. Les auteurs concluent que l'administration rectale de methohexitone dix pour cent $25 \mathrm{mg} \cdot \mathrm{kg}^{-1}$ et un pour cent methohexitone $15 \mathrm{mg} \cdot \mathrm{kg}^{-1}$ sont également efficaces pour l' induction de l'anesthésie chez les enfants et que ces deux modes sont significativement plus efficaces que l'administration rectale de dix pour cent de methohexitone à dose de $15 \mathrm{mg} \cdot \mathrm{kg}^{-1}$. 